\title{
Trade Game Akuntasi Untuk Siswa Sekolah Menengah Atas
}

\author{
Dwi Iga Luhsasi, Carolina Lita Permatasari \\ dwi.luhsasi@uksw.edu, carolina.permatasari@uksw.edu \\ Pendidikan Ekonomi, FKIP, Universitas Kristen Satya Wacana
}

Accounting Trade Game For High School Students

\begin{abstract}
Almost all students who have difficulty in understanding accounting material. Only a few students can understand thoroughly. Most of the students are oriented only to the result of the exercise from the questions, not the understanding of the process, especially for trading company accounting cycle topic. This material requires more understanding in every process of preparation until the preparation of financial statements. The focus on calculating inventory and cost of goods sold makes students often reluctant to do and understand it. This condition also felt by Sedes Sapientiae High School Semarang students. The more complicated cycle requires more attention, sometimes make the students less patient in understanding the cycle. Based on this condition, a tool is needed to solve the problem, which is the Accounting Trade Game. The aim of this game is to attract more attention to students in the learning process on accounting economics subject especially for trading company accounting cycle. In order to solve this problem, development research was carried out using the Borg and Gall model. This model consists of a preliminary study stage, preparation of a product draft, also development and evaluation of the product. As the result, a tool called Accounting Trade Game is a good tool which means that it can help students in the learning the material.
\end{abstract}

Keywords: Educational Game, Accounting, Trading Company Cycle

Article Info

Received date: 21 Desember 2019 Revised date: 8 Januari $2020 \quad$ Accepted date: 22 Januari 2020

\section{PENDAHULUAN}

Semakin berkembangnya ilmu pengetahuan dan teknologi serta tuntutan dunia pendidikan media pembelajaran merupakan komponen pembelajaran yang harus dirancang oleh guru. Berkurangnya minat peserta didik dalam proses belajar mengajar juga merupakan masalah yang serius didunia pendidikan. Guna membantu proses pembelajaran, digunakan alat bantu sebagai penyampai materi pelajaran. Alat ini disebut dengan media pembelajaran. Manfaat media pembelajaran tidak hanya berfungsi sebagai media penyampai materi, tetapi juga berfungsi sebagai penarik perhatian peserta didik agar lebih tertarik dalam proses pembelajaran. Selain itu, penggunaan media pembelajaran dapat membantu siswa dalam mengembangkan kemampuan pemecahan masalah (Nomieni \& Manu, 2018: 228).

Menurut Sumiharsono \& Hasanah (2018: 4) ada beberapa manfaat media dalam proses belajar mengajar, yaitu proses pembelajaran akan lebih menarik perhatian peserta didik, sehingga dapat menumbuhkan motivasi belajar bagi peserta didik. Motivasi yang tinggi pada peserta didik akan membuat peserta didik lebih semangat dalam belajar, sehingga diharapkan hasil dan prestasi belajar peserta didik juga akan meningkat (Hapsari, 2017: 8; Warkintin \& Mulyadi, 2019: 90). Kemudian banyaknya bahan materi pembelajaran, dengan adanya media pembelajaran maka akan lebih jelas maknanya sehingga peserta didik dapat lebih memahami dan menguasaan materi secara maksimal dengan demikian mencapaian tujuan pembelajaran lebih mudah. Di samping itu, metode mengajar akan lebih bervariasi dengan menggunakan model-model pembelajaran, mengajar tidak hanya dengan metode ceramah yaitu dengan komunikasi verbal melalui penuturan kata-kata oleh guru, dengan adanya media pembelajaran akan membuat peserta didik tidak bosan dan guru tidak kehabisan tenaga karena terus menerus menjelaskan (Sugianto, Wibowo, dan Oktaviani, 2017: 179). Manfaat berikutnya dengan adanya media pembelajaran peserta didik dapat lebih banyak melakukan kegiatan belajar, sebab tidak 
hanya mendengarkan penjelasan guru secara konvensional, tetapi peserta didik juga dituntut untuk ada aktivitas lain seperti mengamati, mensimulasikan, memerankan, dan lain-lain.

Media pebelajaran diperlukan pada setiap pelajaran khususnya untuk pelajaran yang memerlukan pemahaman dan analisis mendalam. Seperti halnya pelajaran akuntansi yang memerlukan pemahaman dan analisis dalam setiap siklusnya. Penelitian Hamzah (2013: 1) mengungkapkan, akuntansi termasuk pelajaran yang sulit menurut peserta didik, persepsi peserta didik mengenai sulitnya mempelajari akuntansi diduga karena proses belajar belum dilakukan secara aktif, padahal keaktifan peserta didik dalam proses belajar dapat menjadikan belajar lebih bermakna. Makna dalam hal ini merupakan hasil bentukan peserta didik sendiri yang bersumber dari apa yang mereka lihat, rasakan dan alami. Sebagai dampak dari sulitnya pelajaran akuntansi ini, tidak sedikit peserta didik yang kurang tertarik dengan mata pelajaran akuntansi. Peserta didik cenderung acuh dan tidak memperhatikan materi-materi tersebut.

Kemendikbud (2016: 160) menyusun materi akuntansi berdasarkan Kurikulum 2013 terdiri dari akuntansi sebagai sistem informasi, konsep persamaan dasar akuntansi, tahapan siklus akuntansi pada perusahaan jasa, tahap siklus akuntansi pada perusahaan dagang. Bahasan akuntansi sebagai sistem informasi bertujuan untuk mengenalkan dasar dari akuntansi kepada peserta didik. Belum terdapat perhitungan-perhitungan didalamnya. Sementara itu, dalam konsep persamaan akuntansi sudah dimulai pengenalan perhitungan akuntansi kepada peserta didik dengan kata kunci "balance" yang berarti harta sama dengan hutang ditambah modal. Selanjutnya masuk pada pembahasan siklus akuntansi perusahaan jasa. Karakteristik perusahaan yang kegiatan utamanya menawarkan jasa dan tidak memiliki produk yang dijual, maka pencatatan transaksi dan siklusnya masih relatif sederhana. Pada bahasan yang terakhir, yaitu siklus akuntansi perusahaan dagang inilah yang sering kali sulit dipahami oleh peserta didik. Sering kali dengan adanya tahapan dan perhitungan yang lebih rumit, peserta didik enggan untuk berlatih. Oleh karena itu, terdapat kemungkinan besar media pembelajaran dapat membantu peserta didik mulai tertarik untuk memahami siklus perusahaan dagang.

Sama halnya dengan masalah yang terjadi secara umum, pada SMA Sedes Sapientiae Semarang fenomena tersebut juga terjadi. Berdasarkan pengamatan awal, peserta didik merasa materi akuntansi yang disampaikan secara konvensional kurang mudah untuk dipahami. Saat proses pembelajaran, peserta didik lebih fokus pada hasil akhir dari siklus akuntansi saja. Seperti dalam pembuatan persamaan akuntansi, neraca saldo, dan materi lain yang memerlukan hasil akhirnya seimbang/ balance. Hasil yang seimbang menjadi fokus dari pengerjaan soal-soal materi tersebut. Sementara itu, perlu dipahami lebih dalam mengenai proses analisis setiap transaksi yang ada disetiap tanggalnya. Pemahaman tersebut pada akhirnya dapat memberikan hasil akhir yang benar pula. Namun peserta didik pada sekolah tersebut mengesampingkan pemahaman pada proses pencatatan dari awal. Ditambah dengan jenuhnya soal-soal kasus yang cenderung terdiri dari banyak transaksi.

Terutama pada materi siklus akuntansi perusahaan dagang, peserta didik di SMA Sedes Sapientiae mengalami kecenderungan kurang dapat memahami materi tersebut. Siklus ini merupakan silklus yang paling rumit pada keseluruhan materi akuntansi SMA. Tingkatan kesukaran inilah yang membuat peserta didik tidak jarang menyerah untuk memahami secara mendalam. Dampaknya, peserta didik akan cenderung acuh dan kurang tertarik untuk mencari tahu penyelesaian setiap tahap yang ada pada siklus. Tentunya peserta didik akan selalu mementingkan hasil akhirnya saja. Adanya fenomena ini, maka diperlukan alat bantu dalam proses pembelajaran yang dapat membantu menarik perhatian peserta didik. Tidak hanya terfokus pada hasil akhir saja namun juga pada setiap proses siklus akuntansi.

Di sisi lain, terdapat beberapa penelitian tentang media pembelajaran berupa media digital yang telah dilakukan oleh Krasna (2014); Ali (2009); Darmawan (2016), dapat memberi dorongan kepada guru untuk membuat media simulasi guna memudahkan peserta didik belajar akuntansi usaha dagang. Berdasarkan penelitian-penelitian sebelumnya, masih jarang penelitian yang mendesain permainan untuk materi siklus akuntansi perusahaan dagang. Oleh karena itu, penelitian ini perlu untuk dilakukan guna menambah media pembelajaran akuntansi. Media pembelajaran yang dapat digunakan di SMA Sedes Sapientiae Semarang disebut dengan Trade Game, sebuah media yang dibuat berdasarkan pada aturan-aturan dalam permainan Monopoli, tetapi disesuaikan dengan aturan transaksi usaha dagang sesuai kompetensi dasar yang harus dipahami peserta didik. Media simulasi modifikasi dari permainan Monopoli Dagang, diharapkan dapat membantu peserta didik dalam memahami materi siklus akuntansi perusahaan dagang. 


\section{KAJIAN PUSTAKA}

Media merupakan suatu grafik, fotografi, elektronik, atau alat-alat mekanik yang disajikan secara lisan maupun visual untuk menjelaskan proses atau informasi. Media juga sebagai sarana komunikasi yang merujuk pada semua hal yang membawa informasi antara sumber dan penerima dalam hal ini adalah pengajar dan pembelajar (Smaldino, Lowther, dan Russell 2011: 7). Bagi guru, media merupakan alat bantu untuk mendukung proses pembelajaran yang dilakukan di kelas. Media dapat menciptakan kondisi yang memungkinkan pembelajar untk menerima pengetahuan, keterampilan, dan sikap melalui orang, bahan, alat, mapun peristiwa yang menjadi media itu sendiri (Anitah, 2012: 6).

Salah satu media yang dapat digunakan untuk mendukung pembelajaran adalah media interaktif. Media interaktif merupakan sistem yang menyajikan dan menggabungkan visual, audio, dan video dengan disertai kontrol untuk memudahkan siswa dalam mendengar, melihat, dan memberikan respon secara aktif (Anitah, 2012: 6). Media interaktif dapat juga diartikan sebagai permainan instruksional berbasiskan pada komputer yang menggabungkan beberapa aksi permainan dan keterampilan dengan menggunakan perangkat keras pada komputer seperti keyboard dan mouse. Satu cara yang dapat dilakukan untuk membuat dan mengembangkan media interaktif adalah menggunakan program Microsoft Power Point. Microsoft Power Point adalah program presentasi buatan Microsoft yang digunakan untuk membuat tampilan presentasi atau permainan interaktif dari bentuk sederhana sampai pada bentuk yang kompleks. Program ini telah disertai beberapa fitur yang memungkinkan penggunanya untuk menambahkan script atau perintah sehingga tampilan hasil akhir dapat menjadi lebih menarik. Hampir semua perangkat notebook atau komputer telah dilengkapi dengan program ini sehingga semua pengguna dapat mempelajari program ini secara mandiri khususnya guru dalam membuat dan mengembangkan media interaktif sederhana untuk mendukung proses pembelajaran di kelas.

Pembuatan dan pengembangan media interaktif berupa Trade Game Siklus Akuntansi didasarkan pada pembelajaran untuk jenjang sekolah menengah sesuai dengan kurikulum yang berlaku di Indonesia saat ini. Kurikulum yang berlaku di sekolah-sekolah pada saat ini mengintegrasikan berbagai kompetensi bagi pengetahuan, keterampilan, nilai atau sikap pembelajaran serta pemikiran yang kreatif sehingga siswa dapat melakukan proses pembelajaran secara komprehensif (Sutrijo \& Sri, 2005: 6). Proses pembelajaran yang dilakukan juga menggunakan pendekatan saintifik dimana proses pembelajaran mencakup tiga ranah (sikap, pengetahuan, dan keterampilan) dimana masing-masing ranah saling melengkapi agar proses pembelajaran menjadi seimbang.

Pembuatan dan pengembangan media interaktif Trade Game dilakukan dengan bantuan Microsoft Power Point agar guru dan siswa mudah mengoperasikannya (Putri \& Sibuea, 2014) mengingat Microsoft Power Point hampir dimiliki oleh setiap perangkat komputer atau notebook. Media Trade Game dibuat dan dikembangkan dengan mengadopsi permainan monopoly dimana pemain memainkan bidak untuk sampai pada titik dimana pemain dapat melakukan transaksi pembelian maupun penjualan. Makin banyak transaksi dan kepemilikan aset pada permainan, maka dapat menjadi pemenang dalam permainan monolopy sehingga permainan menjadi lebih menarik terlebih jika permainan ini diaplikasikan dalam pembelajaran (Popalia, 2017).

Media interaktif dapat memberikan beberapa dampak positif bagi proses pembelajaran. Media interaktif yang berupa permainan digital dapat membuat proses pembelajaran menjadi lebih berkesan dan menarik (Hikam, Kariada, dan Santosa, 2013). Selain itu, materi pembelajaran juga dapat tersampaikan kepada siswa dengan efektif (Fokides dan Atsikpasi, 2016; Ng, Lui, dan Kwok, 2013). Media interaktif yang berupa permainan digital dianggap sebagai salah satu media yang sangat praktis untuk digunakan sebagai pendamping dan pendukung proses pembelajaran di kelas sehingga siswa menjadi lebih termotivasi dalam mengikuti proses pembelajaran (Ciampa, 2014; Chung dan Wu, 2017; Wagner, 2017) dan dapat menjadi sumber belajar alternatif bagi siswa (Ng, Lui, dan Kwok, 2015).

\section{METODE PENELITIAN}

Penelitian ini termasuk dalam penelitian pengembangan menggunakan Microsoft Power Point. Pembuatan dilakukan dengan modifikasi sehingga tampilannya menyerupai sebuah game. Produk luaran dari penelitian ini yaitu Trade Game. Tahapan yang digunakan dalam penelitian ini mengadaptasi model pengembangan dari Borg \& Gall dalam Sukmadinata (2007: 164) yang dapat dilihat dari bagan berikut: 
Trade Game Akuntasi Untuk Siswa Sekolah Menengah Atas

(Dwi Iga Luhsasi, Carolina Lita Permatasari)

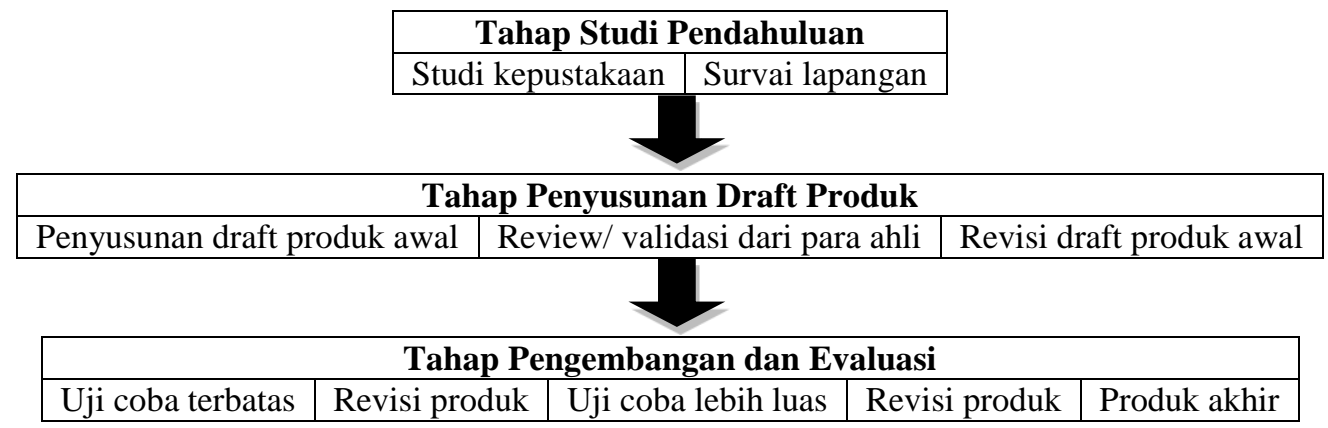

\section{Gambar 1. Tahapan Penelitian dan Pengembangan}

Berdasarkan tahapan tersebut, penelitian ini melakukan uji pakar dan uji pada siswa. Uji pakar terdiri dari uji pakar materi dan uji pakar teknologi. Angket yang digunakan dalam penelitian ini mengembangkan angket yang ada dalam komponen dan isntrumn pengembangan bahan ajar berbasis TIK (Kemendiknas, 2010,18-21). Ada lima skor yang digunakan dalam angket. Skala Likert dengan skor 1 yang artinya sangat tidak setuju hingga skor 5 yang artinya sangat setuju. Kelayakan produk ini, diukur dari hasil uji pakar dan uji coba kepada siswa. Draft produk nantinya akan diuji oleh pakar materi dan teknologi. Dilakukan revisi sesuai dengan catatan yang diberikan oleh kedua pakar.

Data yang diperoleh dari hasil validasi pakar materi, media, dan angket uji coba kepada peserta didik dianalisis menggunakan pedoman analisis kuantitatif yang mengacu pada pedoman konvensi skala likert (Sugiyono, 2010:93). Instrumen pengumpulan data berupa angket uji validasi pakar dan uji coba telah diuji reliabilitasnya yaitu masing-masing sebesar 0,863 dan 0,884 . Tahap selanjutnya yaitu uji coba kepada siswa SMA Sedes Sapientiae Semarang. Setiap uji yang dilakukan, baik uji validasi pakar dan uji coba, digunakan patokan pada tabel 1 (Purwanto,2013) berikut.

Tabel 1. Kategori Berdasarkan Persentase
\begin{tabular}{|ll}
\hline Persentase (NP) & Kategori \\
\hline $86 \%-100 \%$ & Sangat baik \\
\hline $76 \%-85 \%$ & Baik \\
\hline $60 \%-75 \%$ & Cukup baik \\
\hline $55 \%-59 \%$ & Kurang baik \\
\hline$\leq 54 \%$ & Tidak baik \\
\hline
\end{tabular}

Pada tabel tersebut, nilai persentase didapat dari skor mentah perolehan (R) dibagi skor maksimum (SM) lalu dikalikan seratus. Jika ditulis dalam notasi matematika dapat dilihat pada rumus berikut.

$$
\mathrm{NP}=\frac{R}{S M} \times 100
$$

\section{HASIL PENELITIAN DAN PEMBAHASAN}

\section{Tahap Studi Pendahuluan}

Tahap pertama meliputi proses mengkaji teori dan konsep yang digunakan pada penelitian ini. Kajian pustaka sudah dilakukan sebelumnya. Banyak penelitian sebelumnya yang meneliti mengenai media pembelajaran. Krasna (2014) menyatakan bahwa video pembelajaran dapat digunakan untuk kualitas belajar siswa yang lebih baik lagi. Video pembelajaran merupakan salah satu media pembelajaran yang saat ini lebih diminati para siswa dalam proses pembelajaran. Video pembelajaran juga dapat digunakan dalam memahami aplikasi-aplikasi akuntansi seperti MYOB (Darmawan,2016). Adanya media yang menarik membuat siswa lebih fokus lagi dalam proses belajarnya.

Media pembelajaran yang interaktif inilah yang membuat proses belajar mengajar lebih menarik (Ali, 2009). Banyak bidang dan mata pelajaran yang dapat mengaplikasikan media pembelajaran yang membuat siswa lebih aktif. Berdasarkan beberapa penelitian sebelumnya ternyata media pembelajaran memiliki peran yang penting. Adanya media pembelajaran yang menarik inilah yang menjadi salah satu faktor siswa lebih fokus. Anitah (2012) mengatakan bahwa terdapat banyak media pembelajaran yang dapat membuat proses pembelajaran lebih berkualitas, salah satunya adalah 
permainan. Seperti halnya temuan yang ada pada penelitian-penelitian sebelumnya, terlihat bahwa media pembelajaran sampai saat ini masih menjadi perbincangan dan topik yang menarik. Khususnya untuk bidang akuntansi masih sedikit yang membuat dan meneliti terkait media pembelajaran khususnya permainan. Oleh karena itu, tujuan dari penelitian ini guna mengembangkan media pembelajaran berbasis permainan pada materi akuntansi perusahaan dagang.

\section{Tahap Penyusunan Draft Produk}

Media pembelajaran berupa permainan ini memiliki kemudahan untuk diakses oleh para penggunanya. Pada permainan ini hanya dibutuhkan seperangkat laptop atau computer beserta dengan LCD untuk menayangkan setiap langkah pada permainan ini. Permaian yang meliputi akuntansi perusahaan dagang ini diberikan nama Trade Game. Pembuatan alat pelajaran dilakukan dengan menggunakan program Microsoft Power Point dan dirancang sedemikan rupa sehingga sesuai dengan kebutuan kompetensi dasar yang harus dikuasai siswa yaitu memahami dan dapat melakukan pencatatan transaksi transaksi usaha dagang. Trade Game adalah media simulasi yang dibuat oleh untuk mempermudah siswa dalam memahami pencatatan jurnal umum dan jurnal khusus pada akuntansi usaha dagang. Media ini didesain sedemikan rupa sehingga siswa mengalami sendiri apa yang terjadi pada saat transaksi, mengapa akun tersebut masuk pada sebelah debet, mengapa pada kredit.

Aturan Trade Game mirip dengan permainan Monopoly bedanya adalah, yang mereka beli dan jual adalah toko atau usaha dagang, tidak ada kotak dana umum dan kesempatan tetapi kotak pandora box. Permainan ini dilengkapi dengan siklus akuntansi perusahaan dagang secara utuh dibandingkan penelitian Putra \& Nugroho (2016) yang hanya menyajikan materi jurnal penyesuaian; penelitian Asrini (2017) yang menyajikan materi pengayaan merchandise inventory; dan penelitian Rasidi, Wahjoedi, \& Wijaya (2016) yang memaparkan ide tentang pengembangan accounting board game. Penyajian materi siklus akuntansi perusahaan dagang secara lengkap pada Trade Game dimaksudkan supaya peserta didik memiliki pemahaman yang komprehensif dan berkesinambungan guna memahami materi siklus akuntansi perusahaan dagang. Pandora box terdapat retur pembelian, retur penjualan, berbagai beban yang timbul dan semua transaksi yang mungkin terjadi pada usaha dagang. Pada permainan Trade Game siswa dikelompokkan menjadi $4-5$ kelompok dan satu kelompok terdiri dari $5-6$ orang, namun untuk jumlah kelompok dapat menyesuaikan jumlah siswa pada kelas yang ada. Masing-masing siswa yang tergabung kedalam kelompok telah mendapat peran dan kerjanya, ada siswa yang mengoperasikan laptop, ada siswa yang bertugas untuk mencatat jurnal khusus, jurnal umum, dan mencatat setiap transaksi yang ada, ada siswa yang mencatat riwayat perjalanan Trade Game pada papan tulis, serta ada siswa yang memegang uang dan berurusan dengan Bank. Untuk mempermudah pemahaman transaksi yang terjadi pada usaha dagang maka dibuatlah kartu pandora box yang berisi transaksi yang didesain sesuai dengan board Trade Game pada Microsoft Power Point.

Permainan ini dimulai pada petak START dan berjalan seterusnya sesuai dengan angka-angka yang tertunjuk pada dadu. Pemain yang berhenti di atas sebuah Toko atau Usaha Dagang yang belum dimiliki oleh lain pemain, berhak membelinya dari Bank dengan harga yang telah ditentukan di papan permainan. Kalau pemain tersebut tak berhasrat membeli Toko atau Usaha Dagang tadi, maka Bank berhak menjualnya kepada pemain lain. Tujuan utama memiliki Toko atau Usaha Dagang sebanyak mungkin ialah memungut sewa dari pemain yang berhenti di atas tanah milik tersebut. Apabila pemain berhenti di bagian Soal maka pemain berhak menjawab pertanyaan yang ada, jika pemain dapat menjawab dengan benar maka pemain akan mendapatkan uang tunai Rp. 200.000 dan apabila pemain tidak dapat menjawab soal maka pemain dapat masuk ke dalam penjara. Apabila pemain ingin keluar dari penjara maka ia harus mengocok dadu hingga keluar mata dadu bernomor 6 dan memiliki kesempatan mengocok dadu sebanyak 3 kali. Apabila pemain berhenti di bagian beban maka pemain berhak membayar beban itu kepada Bank dan mencatat transaksi yang ada. Lalu jika pemain berhenti di bagian gambar uang makan pemain berhak mendapatkan uang sesuai dengan nominal yang berada di balik slide yang ada.

Jika pemain berhenti di bagian Penjualan maka pemain dapat melakukan transaksi penjualan dengan Toko atau Usaha Dagang yang telah ditentukan pada slide, apabila Toko atau Usaha Dagang belum dimiliki oleh pemain yang lain maka tidak ada transaksi yang terjadi. Apabila pemain berhenti di bagian Pembelian Kartu dalam Pandora Box berisi transaksi transaksi Usaha Dagang yang terjadi, para pemain wajib mengikuti perintah yang ada di dalam kartu Pandora Box. Pemain yang sudah sampai ke garis finish berhak mengulang kembali permainan dimulai dari garis start sampai 2 kali putaran. 
Trade Game Akuntasi Untuk Siswa Sekolah Menengah Atas

(Dwi Iga Luhsasi, Carolina Lita Permatasari)

apabila telah melaksanakan 2 kali putaran maka permainan selesai, jurnal khusus, jurnal umum, dan transaksi dikumpulkan kepada guru dan pemain yang dinyatakan menang adalah pemain yang berhasil mengumpulkan uang terbanyak. Berikut gambaran papan Trade Game.

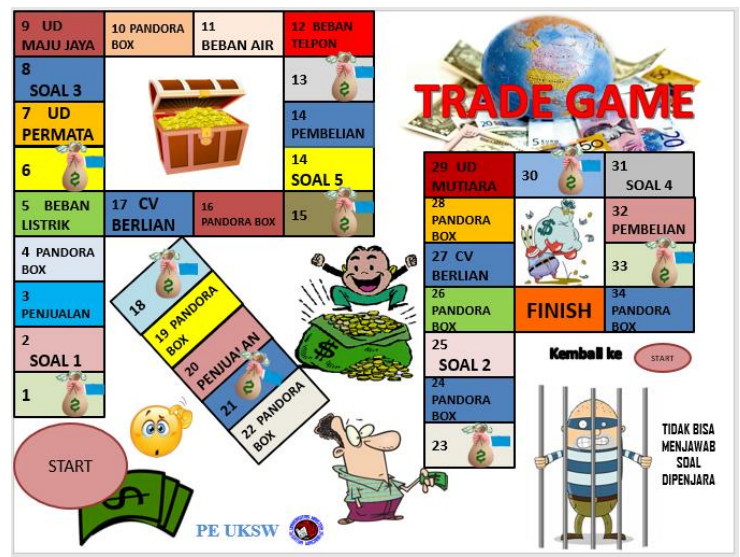

Gambar 1. Tampilan Trade Game

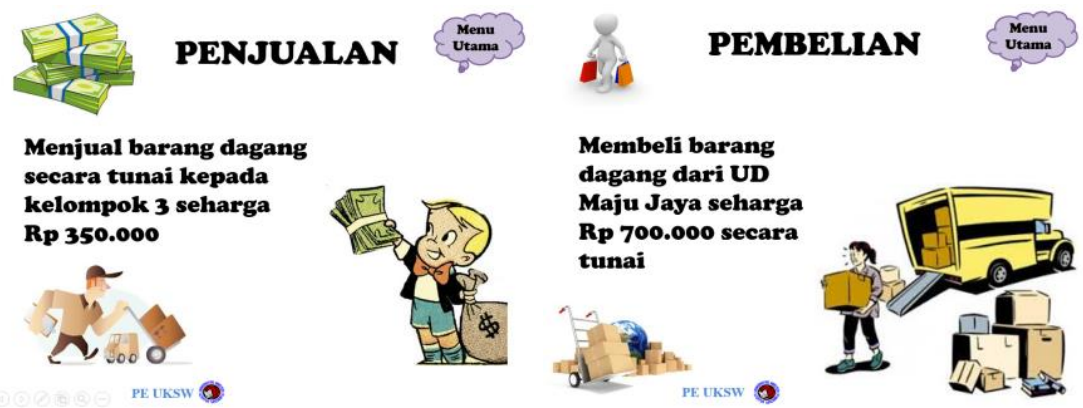

Gambar 2. Contoh Tampilan Soal Transaksi
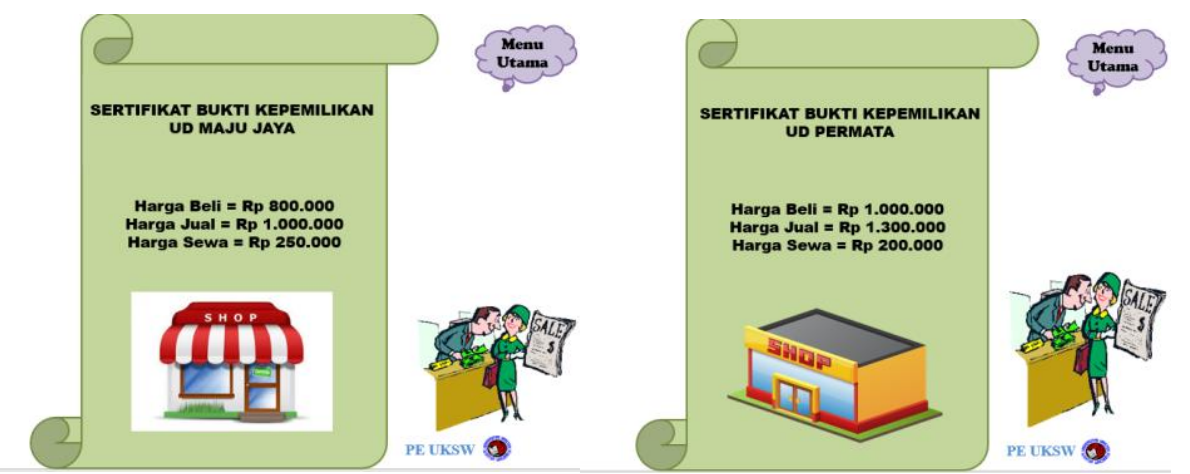

Gambar 3. Contoh Sertifikat Bukti Kepemilikan

Tabel 2. Hasil Validasi Pakar Materi

\begin{tabular}{lllll}
\hline No. & \multicolumn{1}{c}{ Aspek } & Skor & Persentase & \multicolumn{1}{c}{ Kategori } \\
\hline 1 & Substansi Materi & 4,5 & $90 \%$ & Sangat baik \\
\hline 2 & Desain Pembelajaran & 3,7 & $74 \%$ & Cukup baik \\
\hline Rata-rata & 4,1 & $82 \%$ & Baik \\
\hline
\end{tabular}

Pada tabel 2 menunjukkan bahwa materi yang ada pada Trade Game termasuk dalam kategori baik. Hal ini dilihat pada nilai rata-rata 4,1 atau jika di presentasikan sebesar $82 \%$. Aspek substansi materi termasuk dalam kategori sangat baik. Sedangkan aspek desain pembelajaran termasuk dalam kategori cukup baik. Catatan penting yang ditambahkan oleh pakar materi untuk menambahkan soalsoal yang lebih beragam supaya dalam satu kali permainan, siswa dapat membahas lebih banyak contoh transaksi. Pakar yang kedua yaitu pakar teknologi. Hasil validasi pakar teknologi dapat dilihat pada tabel 3 berikut. 
Tabel 3. Hasil Validasi Pakar Media

\begin{tabular}{lllll}
\hline No. & \multicolumn{1}{c}{ Aspek } & Skor & Persentase & Kategori \\
\hline 1 & Tampilan Komunikasi Visual & 3,7 & $74 \%$ & Cukup baik \\
\hline 2 & Pemanfaatan software & 3,0 & $60 \%$ & Cukup baik \\
\hline Rata-rata & 3,3 & $66 \%$ & Cukup baik \\
\hline
\end{tabular}

Berdasarkan hasil validasi tersebut, Trade Game termasuk dalam kategori cukup baik dengan skor 3,3 atau setara dengan 66\%. Pada validasi pakar teknologi ini terdiri dari dua aspek. Aspek pertama yaitu aspek tampilan komunikasi visual yang mendapatkan kategori cukup baik. Aspek kedua yaitu aspek pemanfaatan software mendapat skor 3,0 dengan kategori cukup baik. Hasil tersebut disertai dengan masukan pakar yaitu perlu ditambahkan audio pada bagian-bagian tertentu.

\section{Tahap Pengembangan dan Evaluasi}

Tahap ini Trade Game telah melewati tahap evaluasi pakar berdasarkan angket validasi dan evaluasi pakar materi dan media sehingga media Trade Game siap untuk diuji cobakan. Tahap ujicoba dilakukan dengan cara mengaplikasikan Trade Game pada dua kelas. Pada saat akhir permainan, para siswa diminta untuk mengisi angket yang terkait dengan permainan tersebut mulai dari susbtansi materi, desain pembelajaran, tampilan komunikasi visual, dan pemanfaatan software. Setelah dilakukan uji coba pada 50 siswa yang terdiri dari dua kelas, didapatkan hasil skor rata-rata sebesar 3,8 dengan presentasi $76 \%$. Skor rata-rata ini didalamnya terdiri dari empat aspek. Dimana aspek tertinggi diperoleh aspek substansi materi sebesar 4,2 dengan presentase $84 \%$. Serta aspek terendah ada pada aspek pemanfaatan software dengan skor 3,3 yang setara 66\%. Hasil ini dapat dilihat pada tabel 4 .

Tabel 4. Hasil Pengisian Angket Uji Coba

\begin{tabular}{llccl}
\hline No. & \multicolumn{1}{c}{ Aspek } & Skor & Persentase & \multicolumn{1}{c}{ Kategori } \\
\hline 1 & Substansi Materi & 4,2 & $84 \%$ & Baik \\
\hline 2 & Desain Pembelajaran & 3,7 & $74 \%$ & Cukup baik \\
\hline 3 & Tampilan Komunikasi Visual & 4,1 & $82 \%$ & Baik \\
\hline 4 & Pemanfaatan software & 3,3 & $66 \%$ & Cukup baik \\
\hline & Rata-rata & 3,8 & $76 \%$ & Baik \\
\hline
\end{tabular}

Pada saat permainan ini diaplikasikan dari kedua kelas tersebut, para siswa tertarik dengan materi yang ada dalam Trade Game. Siswa-siswa antusias dengan adanya permainan ini. Hal ini serupa dengan yang dikatakan oleh Ali (2009). Mereka menjadi lebih tertantang untuk menjawab setiap pertanyaan dalam permainan. Berusaha untuk memenangkan permainan dengan menjawab setiap pertanyaan dengan benar. Ada beberapa catatan yang diutarakan oleh beberapa siswa. Kurangnya audio untuk latar belakang suara pada setiap pertanyaan yang berhasil dijawab benar. Serta ada beberapa soal yang diulang sehingga lebih mudah tertebak jawaban yang benar. Hal-hal ini yang menjadi acuan untuk dilakukan perbaikan oleh peneliti.

Penyajian materi yang menarik seperti halnya permainan Trade Game lebih tertarik dan menyimak setiap materi. Anitah (2012) juga sependapat dengan pernyatan tersebut. Permainan yang dilengkapi dengan berbagai warna dan animasi membantu materi akuntansi perusahaan dagang lebih menyenangkan. Penyajian dengan media interaktif seperti inilah yang dapat memberikan suasana baru dalam proses belajar mengajar di kelas (Darmawan, 2016; Krasna, 2014; Hamzah, 2013). Adanya situasi dan suasana permainan seperti ini membuat setiap pertanyaan transaksi menjadi lebih menarik dan tertantang untuk dipecahkan. Situasi pertandingan memacu untuk semangat para siswa meningkat. Materi yang disampaikan dengan menggunakan Trade Game ini dirasa memberikan manfaat lebih dalam proses pembelajaran sehingga tujuan dari pendalaman materi ini tercapai. Permainan ini juga memberikan pemahaman bagi siswa dengan efektif.

\section{SIMPULAN DAN SARAN}

Berdasarkan hasil yang diperoleh, dapat disimpulkan bahwa Trade Game dalam pembelajaran akuntansi khususnya pada materi akuntansi perusahaan dagang layak untuk diaplikasikan. Ini dibuktikan dengan hasil uji validasi pakar materi, pakar teknologi, dan uji coba kepada para siswa yang berada para kategori cukup baik dan baik. Rata-rata pada uji validasi pakar materi menunjukan kategori 
Trade Game Akuntasi Untuk Siswa Sekolah Menengah Atas

(Dwi Iga Luhsasi, Carolina Lita Permatasari)

baik dengan skor 4,1. Pakar teknologi menunjukan kategori cukup baik dengan skor 3,3 atau sebesar $66 \%$. Sementara itu, uji coba pada para siswa tergolong pada kategori baik dengan skor 3,8 dengan presentase $82 \%$.

Di sisi lain, permainan Trade Game ini memiliki keterbatasanya yaitu kurangnya variasi transaksi yang ada dalam permainan ini. Serta materi yang ada dalam permainan hanya terdiri dari satu materi mengenai akuntansi perusahaan dagang saja. Oleh karena itu, untuk penelitian-penelitian selanjutnya dapat membuat permainan sejenis dengan materi-materi akuntansi yang lainnya. Harapannya agar pembelajaran akuntansi srtiap materi dapat dipahami dengan lebih antusias menggunakan cara-cara yang menarik.

\section{UCAPAN TERIMAKASIH}

Ucapan terimakasih penulis sampaikan kepada Fakultas Keguruan dan Ilmu Pendidikan Universitas Kristen Satya Wacana Salatiga telah memberi dukungan dana pada penulisan artikel ini. Penulis ucapkan terimakasih juga kepada para mahasiswa yang menjadi sampel penelitian dan pihakpihak yang membantu berjalannya proses pengambilan data sampai penulisan artikel sehingga artikel ini dapat terselesaikan.

\section{DAFTAR PUSTAKA}

Ali, Muhamad. 2009. Pengembangan Media Pembelajaran Interaktif Mata Kuliah Medan Elektromagnetik. Jurnal Edukasi Elektro. 5(1): 11-18.

Anitah, Sri. 2012. Media Pembelajaran. Surakarta: Yuma Pustaka.

Asrini, Y. P. 2017. Pengembangan Media Pengayaan Merchandise Inventory Game Pada Mata Pelajaran Akuntansi Perusahaan Dagang Siswa Kelas XI Akuntansi SMK Negeri Di Surabaya. Jurnal Pendidikan Akuntansi (JPAK), 5(2): 1-7.

Chung, S. M., \& Wu, C. T. 2017. Designing Music Games and Mobile Apps for Early Music Learning. In Serious Games and Edutainment Applications (pp. 57-75). Springer International Publishing.

Ciampa, K. 2014. Learning In a Mobile Age: An Investigation of Student Motivation. Journal of Computer Assisted Learning, 30(1): 82-96.

Darmawan, Reka \& Nugroho, M.A. 2016. The Development of Vlogging as Learning Media to Improve Student's Learning Enthusiasm on MYOB Manufacture (Debt Card) Material. Jurnal Kajian Pendidikan Akuntansi Indonesia Edisi 3.

Fokides, E., \& Atsikpasi, P. 2016. Tablets in Education. Results from The Initiative ETiE, For Teaching Plants to Primary School Students. Education and Information Technologies, 22(5): 1-19.

Hamzah, Ardi. 2013. Pengaruh Sosiologi Kritis, Kreatif, dan Mentalitas terhadap Pendidikan Akuntansi. E-Journal UIN Malang. 2(1): 1-17.

Hapsari, A. 2017. Penerapan Model Pembelajaran Kooperatif Tipe Numbered Heads Together Berbantuan Media Interaktif untuk Meningkatkan Aktivitas dan Prestasi Belajar Siswa. Scholaria: Jurnal Pendidikan Dan Kebudayaan, 7(1): 1-9.

Hikam, A. R., Kariada, N., \& Santosa, K. 2013. Pengembangan Game Edukasi Visual Novel Berbasis Pembangunan Karakter Pada Materi Pelestarian Lingkungan. Journal of Biology Education, 2(2): 148-154.

Kemendikbud. 2016. Kompetensi Inti dan Kompetensi Dasar Pendidikan Dasar dan Menengah. Jakarta. Kementrian Pendidikan Nasional Direktorat Jendral Manajemen Pendidikan Dasar dan Menengah. 1-238

Kemendiknas. 2010. Panduan Pengembangan Bahan Ajar Berbasis TIK. Jakarta: Kementrian Pendidikan Nasional Direktorat Jenderal Manajemen Pendidikan Dasar dan Menengah.

Krasna, Marjan \& Bratina, T. 2014. Video Learning Materials for Better Student's Performance. CECIIC September: 130-137. 
Ng, S. C., Lui, A. K., \& Kwok, A. C. 2015. Easy-to-Learn Piano: A Mobile Application for Learning Basic Music Theory and Piano Skill. In International Conference on Technology in Education (pp. 103-112). Springer Berlin Heidelberg.

Ng, S.C., Lui, A. K., \& Lo, W. S. 2013. An Interactive Mobile Application For Learning Music Effectively. In International Conference on ICT in Teaching and Learning. Springer Berlin Heidelberg: 148-157.

Nomleni, F., \& Manu, T. 2018. Pengembangan Media Audio Visual dan Alat Peraga dalam Meningkatkan Pemahaman Konsep dan Pemecahan Masalah. Scholaria: Jurnal Pendidikan Dan Kebudayaan, 8(3): 219-230.

Popalia, D. 2017. Pengembangan Media Permainan Monopoli Pada Materi Perpajakan Siswa Kelas XI IPS SMAN 1 Porong. Jurnal Pendidikan Ekonomi (JUPE), 5(3): 1-5.

Putra, D. R., \& Nugroho, M. A. 2016. Pengembangan Game Edukatif Berbasis Android Sebagai Media Pembelajaran Akuntansi Pada Materi Jurnal Penyesuaian Perusahan Jasa. Jurnal Pendidikan Akuntansi Indonesia, 14(1): 25-34.

Putri, I. P., \& Sibuea, A. M. 2014. Pengembangan Media Pembelajaran Interaktif Pada Mata Pelajaran Fisika. Jurnal Teknologi Informasi \& Komunikasi dalam Pendidikan, 1(2).

Rasidi, N. D., Wahjoedi, W., \& Widjaja, S. U. M. (2016, December). Perancangan Accounting Board Game (ABG) Untuk Belajar Siklus Akuntansi. In National Conference on Economic Education (pp. 1036-1046).

Smaldino, S.E., Lowther, D.L., \& Russell, J.D. 2011. Instructional Technology and Media for Learning. Jakarta: Kencana Prenada Media Group.

Sugianto, D., Wibowo, D., \& Oktaviani, U. 2017. Improving Listening Skill to Fairytales Using A Hand Puppets Media. Scholaria: Jurnal Pendidikan Dan Kebudayaan, 7(2), 178-189.

Sugiyono. 2010. Metode Penelitian Kuantitatif, Kualitatif \& RND. Bandung: Alfabeta.

Sukmadinata, Nana Syaodih. 2007. Metode Penelitian Pendidikan. Bandung: Remaja Rosda Karya.

Sumiharsono, R. \& Hasanah, H. 2018. Media Pembelajaran: Buku Bacaan Wajib Dosen, Guru, dan Calon Pendidik. Jember: CV. Pustaka Abadi.

Sutirjo \& Sri Istuti M. 2005. Tematik: Pembelajaran Efektif dalam Kurikulum 2004. Malang: Banyumedia Publising.

Wagner, C. 2017. Digital Gamification in Private Music Education. Antistasis, 7(1): 115-121.

Warkintin, W., \& Mulyadi, Y. 2019. Pengembangan Bahan Ajar Berbasis CD Interaktif Power Point Untuk Meningkatkan Hasil Belajar Siswa. Scholaria: Jurnal Pendidikan Dan Kebudayaan, 9(1), 82-92. 